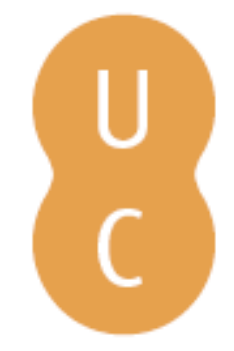

\title{
pommalina
}

\section{Assessing the fire risk in the wildland-urban interfaces of SE France: focus on the environment of the housing}

Autor(es): $\quad$ Ganteaume, Anne; Jappiot, Marielle

Publicado por: Imprensa da Universidade de Coimbra

URL

persistente:

URI:http://hdl.handle.net/10316.2/34227

DOI:

DOI:http://dx.doi.org/10.14195/978-989-26-0884-6_73

Accessed : $\quad$ 26-Apr-2023 12:13:16

A navegação consulta e descarregamento dos títulos inseridos nas Bibliotecas Digitais UC Digitalis, UC Pombalina e UC Impactum, pressupõem a aceitação plena e sem reservas dos Termos e Condições de Uso destas Bibliotecas Digitais, disponíveis em https://digitalis.uc.pt/pt-pt/termos.

Conforme exposto nos referidos Termos e Condições de Uso, o descarregamento de títulos de acesso restrito requer uma licença válida de autorização devendo o utilizador aceder ao(s) documento(s) a partir de um endereço de IP da instituição detentora da supramencionada licença.

Ao utilizador é apenas permitido o descarregamento para uso pessoal, pelo que o emprego do(s) título(s) descarregado(s) para outro fim, designadamente comercial, carece de autorização do respetivo autor ou editor da obra.

Na medida em que todas as obras da UC Digitalis se encontram protegidas pelo Código do Direito de Autor e Direitos Conexos e demais legislação aplicável, toda a cópia, parcial ou total, deste documento, nos casos em que é legalmente admitida, deverá conter ou fazer-se acompanhar por este aviso.

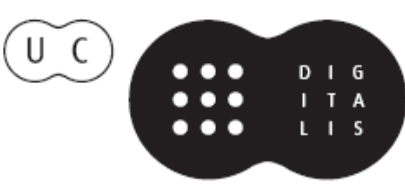




\section{ADVANCES IN}

Forest Fire

\section{RESEARCH}

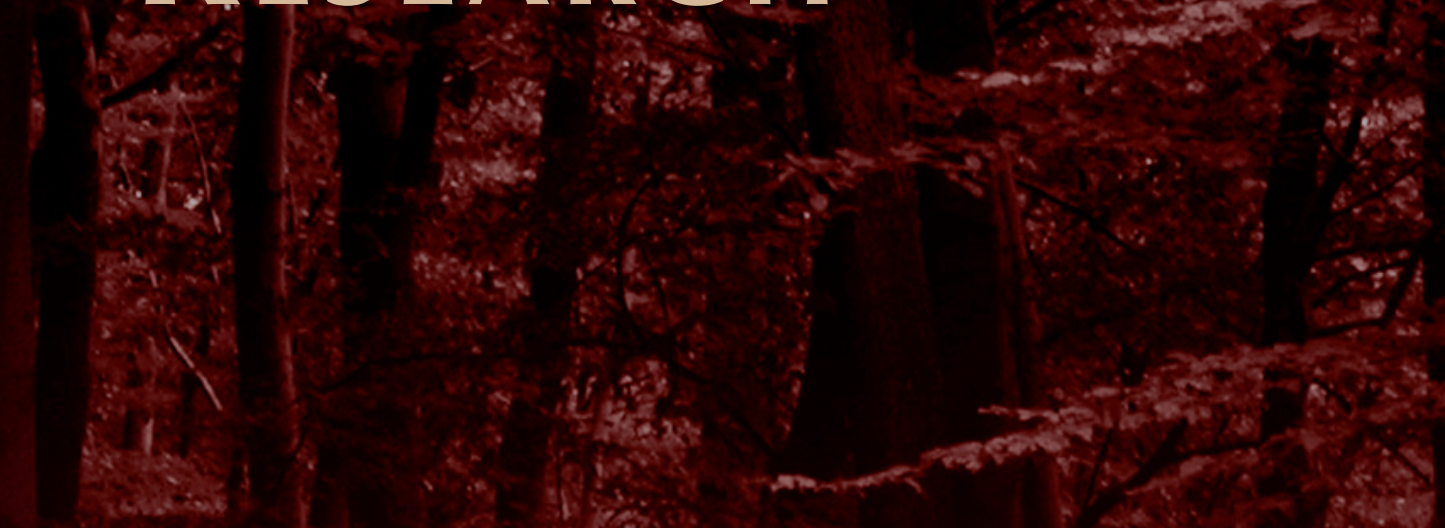

\section{DOMINGOS XAVIER VIEGAS}

\section{EDITOR}




\title{
Assessing the fire risk in the wildland-urban interfaces of SE France: focus on the environment of the housing
}

\author{
Anne Ganteaume, Marielle Jappiot \\ Irstea, UR EMAX, 3275 route de Cézanne- 13183 Aix-en-Provence cedex 5- France. \\ anne.ganteaume@irstea.fr, marielle.jappiot@irstea.fr
}

\begin{abstract}
In order to assess the fire risk in Wildland-Urban Interfaces (WUIs) of SE France according to the environment of the housing, several descriptive parameters (ornamental species, types of vegetation adjoining the environment of the housing, types of fence, structure of the hedges and implementation of the regulation on brush-clearing) assumed to either increase or decrease the fire propagation, thus the fire risk, were surveyed according to the types of WUI (isolated, scattered, dense and very dense clustered), in two different locations (coastal and inland) of the study area (département Bouches du Rhône). The flammability of the most frequent ornamental species was assessed at the levels of live and dead surface fuels.

Results showed that the two areas differed according to the main WUI type, the main ornamental species, the main type of fence, the main type of vegetation adjoining the environment of the housing. There was also a variation of these parameters between the different types of WUI, especially according to the ornamental species. The fire risk, assessed through the parameters surveyed and through the flammability of the main ornamental species, increased from the very dense and dense clustered WUIs to the isolated and scattered WUIs and from the coastal area to the inland area.

The improvement of the knowledge on WUI environment at the small scale will allow an increase in the efficiency of the wildfire prevention targeting the areas most at risk.
\end{abstract}

Keywords: Wildland-Urban Interfaces, wildland fire, fire risk, flammability of ornamental vegetation

\section{Introduction}

In the South of France, urbanization, along with the phenomenon of forest extension is generating new spatial configurations called wildland urban interfaces (WUI). In the context of high urban pressure and the accumulation of wildland biomass, WUIs represent serious issues in terms of fire risk management (Davis 1990; Vélez 1997; Cohen 2000). The WUI is becoming a priority region for fire prevention and suppression (Stephens, 2005) and assessing the risk of forest fire in WUI is essential for wildfire prevention and land management. Indeed, wildfires in these areas are a serious threat to communities in many countries worldwide as they can be extremely destructive, killing people and destroying homes and other structures (Mell et al. 2010; Haynes et al. 2010), thus having ecological, social, and economic consequences. Research using modelling, experiments, and WUI case studies indicates that home ignitability during wildland fires depends on the characteristics of the home and its immediate surroundings, area called the "home ignition zone" (Cohen 2000). A home's ignition potential during extreme wildfires is determined by the characteristics of its exterior materials and design and their response to burning objects, within one hundred feet (30-40 metres), and firebrands (burning embers). Actual case examinations found that most destroyed homes ignite from smaller flames and directly from firebrands and unconsumed vegetation surrounding most destroyed homes (Cohen 2008). Thus, addressing conditions within the home ignition zone can significantly reduce the home ignition potential.

In the present paper, and according to previous works (Stewart et al. 2007; Lampin-Maillet et al. 2009, 2011), we use the term WUI to refer to the conjunction of housing as well as vegetation characteristics and human presence can be measured by the density of houses and other infrastructures (Lampin et al. 2006a, 2006b; Caballero 2004; Camia et al. 2003). A WUI typology has been built regarding the spatial 
organization of residential houses (Lampin-Maillet et al. 2010) and four types of WUI were identified accordingly: (i) isolated (I), (ii) scattered (S) and clustered dwellings divided into (iii) dense clustered (D) and (iv) very dense clustered (VD). The authors of this work hypothesized that the fire behaviour in WUIs was influenced by the pattern of urban areas within a natural landscape and taking into account three variables of fire risk (ignition density, wildfire density and burned area ratio), they showed that isolated and scattered WUI were the most at risk. Hence, it was interesting to explain these results working at a smaller scale, regarding the environment around the housing. At this scale, a first approach assessing the flammability of some ornamental species in SE France was made by Ganteaume et al. (2013a, 2013b).

In the present work, we wanted to assess the fire risk at this small scale, taking into account the area surrounding the housing (Cohen's home ignition zone) which corresponds to the ornamental garden commonly found in WUI of SE France. Within this zone, we recorded several indicators which can enhance (vector of the fire propagation) or mitigate the fire risk such as the main ornamental species whose flammability was assessed in laboratory conditions, the structure of the ornamental hedges, the fence type, the vegetation adjoining the environment of the housing and the implementation of the regulation on brush-clearing. The aims of this work were, first, to describe the environment of the housing in each type of WUI in different locations of the study area, and then to assess the fire risk in these WUIs determining which type was the most at risk according to the environment of the housing.

\section{Methods}

\subsection{Study area}

The study area is located in the département Bouches du Rhône (Northwestern coordinates: $43.655^{\circ} \mathrm{N}$, $5.495^{\circ} \mathrm{E}$; Southeastern coordinates: $43.832^{\circ} \mathrm{N}, 5.672^{\circ} \mathrm{E}$; total area: 508700 ha), one of 15 administrative districts composing Southeastern France (Fig 1) which is among the areas most affected by wildfires (54 fires/year and 1247.3 hectares burned per year in the 2000-2010 period according to the regional forest fire database Prométhée). The main natural fuel types of the study area, located mostly on limestone-derived soils, are Pinus halepensis forests (Quézel 2000) and mixed pine-oak (Quercus ilex and Q. pubescens) forests, often the pre-forest vegetation type before oak forests (Quézel and Barbéro 1992). Shrublands, called "garrigue" on limestone-derived soils, are another dominant fuel that corresponds to the predominant successional stage after woodland degradation (Barbéro $e t$ al., 1998). Wildfires occur frequently in the whole area and overall, the study area is a mosaic of all the previously mentioned types of vegetation and agricultural areas. Because of the difference in climatic conditions between the coastal fringe and the inland part, the study area was divided into two sub-areas (coastal and inland) for sampling, as the variables recorded in the WUI (especially the ornamental vegetation) may differ depending on their location. Thus, 117 housings were surveyed in four coastal locations and 110 housings in five inland locations. 


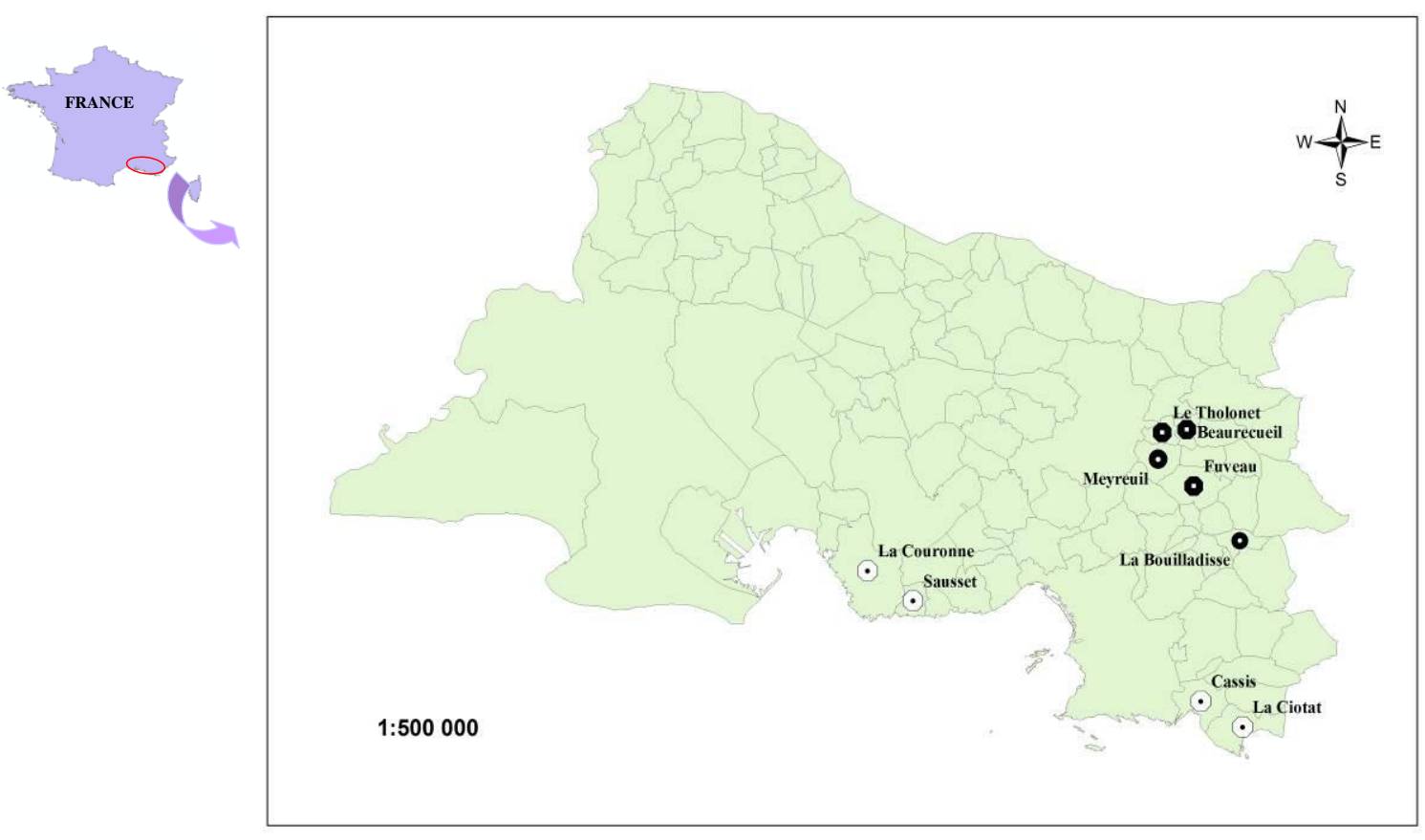

Figure 1. Map of the study area (Département des Bouches du Rhône) in Southeastern France showing where the hedges were surveyed (BD Carto). White spots: coastal area, black spots: inland area

\subsection{Parameters surveyed for the characterization of the area surrounding the housing}

The surveys were also carried out according to the four types of WUI defined by Lampin-Maillet $e t$ al. (2010): isolated, scattered, dense and very dense clustered. The ornamental species present in each hedge, the structure of the hedge (continuous, discontinuous), the fence type (wall, low wall, low wall and wire, wire, none) surrounding the housing, the vegetation adjoining the ignition zone area (forest, shrubland, crops, another ornamental garden) and if the regulation on brush-clearing was implemented or not, were recorded in each survey. Multiple correspondence analysis (MCA) was carried out in order to highlight the relationships between the parameters recorded in the field and the different types of WUI. This multivariate analysis was performed with R software (R 2.11-1, ADE-4 1.5-1 package).

\subsection{Assessing the fire risk according to the flammability of the ornamental species}

The flammability of the most frequent ornamental species was assessed during burning experiments of both live and dead fuel samples which were performed at the Irstea Aix-en-Provence facility. Litters (dead fuels), which are the targeted fuel bed in case of spot fires, were burned on a fire bench (experimental conditions described in Ganteaume et al. 2013a) and the ignitability, sustainability and combustibility variables were recorded during these experiments. Following the definitions of Anderson (1970), these variables were: (i) the ignition frequency (IF in \%) which was computed as the number of successful ignitions relative to the number of trials for a same species; (ii) the time-toignition (TTI in s) which corresponded to the time necessary for the appearance of a flame after the firebrand had been placed on the sample; (iii) the flaming duration (FD in s) and (iv) the number of opposite directions of the sample reached by flames ( 0 to 4 ) assessing the initial flame propagation. Live leaves, which are the targeted fuels during the fire propagation from plant to plant, were burned on an epiradiator (experimental conditions described in Ganteaume et al. 2013b) and their ignitability and sustainability variables were recorded.

Hierarchical cluster analysis was performed on the flammability variables recorded during the burning experiments of live and dead fuel samples to rank the most frequent species from the least flammable to the most flammable. This analysis was performed with $\mathrm{R}$ software (R 2.11-1, ADE-4 1.5-1 package). 


\subsection{Assessing the variation of the fire risk in the study area}

The fire risk was assessed according to the descriptive parameters recorded in the environment of the housing. Multiple correspondence analysis allowed the determination of the types of WUI and the area that were the most at risk and the characterization of the different level of fire risk.

\section{Results and discussion}

\subsection{Results of the surveys in the study area}

Regarding the 227 housings surveyed in the study area, the main types of WUI identified were "very dense clustered" (37\%) and "scattered" (31.3\%) and a total of 20 ornamental species were recorded. The cypress (all species taken into account) was the most common plant regardless of the WUI type (up to $45 \%$ of the ornamental vegetation in the "isolated" WUI type), especially Cupressus arizonica (except in the "dense clustered" type). The other most frequent species were Prunus laurocerasus and Thuya plicata (in scattered WUI), Eleagnus ebbingei and Viburnum tinus (in dense clustered WUI) as well as Nerium oleander and Pittosporum tobira (in very dense clustered WUI). The distribution of the ornamental species varied according to the WUI types (Figure 2). Species characterizing the "dense" and "very dense" clustered types clearly differed and differed also from those characterizing the "isolated" and "scattered" types; these two last types did not form two separated clusters of species.

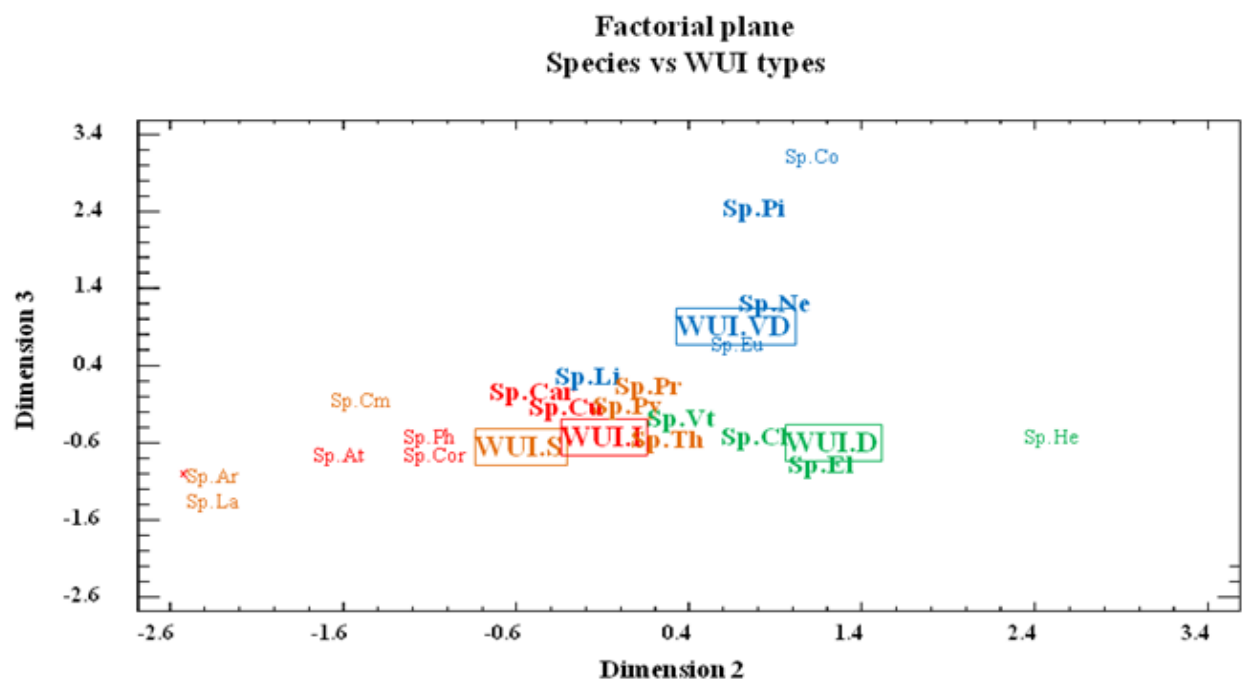

Figure 2. Factorial plane of the MCA showing the characterization of the different WUI types (I: isolated, S: scattered, D: dense clustered, VD: very dense clustered) by the ornamental species (in bold: most frequent species; Ar: Arundo donax, La: Laurus nobilis, At: Atriplex maritimus, Cor: Coronilla sp., Ph: Phyllostachys sp., Cu: Cupressus sempervirens, Cm: Cupressus macrocarpa, Car: Cupressus arizonica, Li: Ligustrum japonicum, Pr: Prunus laurocerasus, Py: Pyracantha coccinea, Vt: Viburnum tinus, Cl: Cupressus leylandii, Th: Thuja occidentalis, El: Eleagnus ebbingei, Eu: Euonymus japonicus, Ne: Nerium oleander, Pi: Pittosporum tobira, Co: Cotoneaster sp., He: Hedera helix).

Among the descriptive parameters recorded in the environment of the housing, we found that the hedges composed of ornamental vegetation were mostly continuous (87\%) and the main types of fence were "low wall + wire" (39\%, mostly in dense and very dense WUI types) and "wire" (35\%, mostly in scattered and isolated WUI types). On the contrary, the "wall" was the less frequent type of fence $(16 \%)$. The main vegetation types adjoining the buffer around the housing were another ornamental garden (43\% especially in dense and very dense WUI types) and forest (31\%, especially in scattered 
and isolated WUI types). In total, $49 \%$ of the houses surveyed were directly adjoining wildland vegetation and the mandatory brush-clearing was implemented at $96 \%$.

\subsection{Results of the spatial variation within the study area}

The very dense clustered WUI was the most frequent type in the coastal area (47\%) whereas the scattered WUI was the most frequent type in the inland area (36\%).

The main ornamental species also differed spatially. Prunus laurocerasus and Pyracantha (in mostly in scattered and very dense types), Eleagnus ebbingei and Cupressus leylandi (mostly in dense type) as well as $C$. sempervirens and $C$. arizonica (mostly in isolated type) were the most frequent species in the inland area whereas Nerium oleander (mostly in scattered, dense and very dense types), Pittosporum tobira (mostlin very dense and isolated types), Thuya plicata (mostly in dense type) and the cypress (all species regardless of the WUI type) were the most frequent in the coastal area.

There was no spatial difference in the type of hedge (mostly continuous) and the main types of fence were "low wall + wire" in the coastal area (49\%) and "wire" in the inland area (53\%).

The main vegetation types adjoining the environment of the housing were another ornamental garden (58\% especially in dense and very dense types) in the coastal area and forest (42\%, especially in scattered and dense types) inland. In total, $30 \%$ of the houses surveyed were directly adjoining wildland vegetation in the coastal area against $70 \%$ in the inland area and the mandatory brush-clearing was implemented at more than $90 \%$ in both areas.

\subsection{Flammability experiments}

Among the 20 species recorded during the surveys, which were hypothesized to be representative of the species planted in the whole study area, eight species were chosen for the study of their flammability, either because of their frequency in the study area, e.g. Prunus laurocerasus (Pr), Pyracantha coccinea (Py), Cupressus sempervirens $(\mathrm{Cu})$ assumed to have the same flammability characteristics as the other species of Cupressus and as Thuya plicata (because of the same foliar structure), Nerium oleander (Ne), Eleagnus ebbingei (El), Ligustrum japonicum (Li) and Pittosporum tobira $(\mathrm{Pi})$, or because of their uniqueness, e.g. Phyllostachys $s p$. (Ph), the only monocotyledon recorded, which may have particular flammability characteristics.

Results of the flammability experiments are presented in table 1. At the litter level, Cupressus sempervirens and Pyracantha coccinea litters ignited very frequently (IF $\geq 90 \%$ ) in contrast of Pittosporum tobira litters (20\%). Litters sampled in the hedges of Ligustrum japonicum and Nerium oleander were the quickest to ignite (47 and 49 s) in contrast of these of Prunus laurocerasus and Pyracantha coccinea (153 s and $188 \mathrm{~s}$ ). The longest flaming duration were recorded in Eleagnus ebbingei, Cupressus sempervirens and Pyracantha coccinea litters (between 145 and $148 \mathrm{~s}$ ) and the shortest in Pittosporum tobira litter (55 s). Initial flame propagation was the best in Ligustrum japonicum litter (on average 3.7 sides of the sample were reached by the flames) in contrast of Cupressus sempervirens litter (on average, 2.4 sides of the sample were reached by the flames). At the live leaf level, Cupressus sempervirens, Eleagnus ebbingei, Phyllostachys sp. and Pyracantha coccinea litters ignited very frequently (IF $\geq 90 \%$ ) in contrast of Ligustrum japonicum and Pittosporum tobira litters (42 and 46\%). Litters sampled in the hedges of Phyllostachys sp. were the quickest to ignite (11 s) in contrast of these of Cupressus sempervirens and Pittosporum tobira (36 s and $30 \mathrm{~s}$ ). Eleagnus ebbingei litters burned the longest (12 s) in contrast of these of Prunus laurocerasus (5 s). 
Table 1. Flammability variables of the litter and live leaf recorded on each species studied (mean and standard deviation; IF: ignition frequency, TTI: time-to-ignition, FD: flaming duration, Ph: Phyllostachys sp., Cu: Cupressus sempervirens, Ne: Nerium oleander, Li: Ligustrum japonicum, El: Eleagnus ebbingei, Pi: Pittosporum tobira, Pr:

Prunus laurocerasus and Py: Pyracantha coccinea)

\begin{tabular}{|c|c|c|c|c|c|c|c|}
\hline & IF_litter(\%) & TTI_litter(s) & FD_litter(s) & FS_litter(\#) & IF_live(\%) & TTI_live(s) & FD_live(s) \\
\hline $\mathrm{El}$ & 57 & $70.71(37.88)$ & $145.12(83.57)$ & $3.47(1.01)$ & 98 & $16.39(5.4)$ & $11.88(3.75)$ \\
\hline $\mathrm{Li}$ & 60 & $46.72(50.77)$ & $86(54.51)$ & $3.72(0.75)$ & 42 & $21.38(8.26)$ & $7.71(4.26)$ \\
\hline $\mathrm{Ph}$ & 70 & $56.24(33.27)$ & $66.10(33.28)$ & $3.43(0.51)$ & 96 & $10.71(4.15)$ & $8.4(3.56)$ \\
\hline $\mathrm{Pi}$ & 20 & $116.85(113.50)$ & $55(45.96)$ & $2.54(1.71)$ & 46 & $29.57(11.73)$ & $8.96(6.8)$ \\
\hline $\mathrm{Ne}$ & 57 & $49.26(36.42)$ & $66.89(22.86)$ & $3.11(1.24)$ & 86 & $23.67(6.81)$ & $8.14(4.2)$ \\
\hline $\mathrm{Pr}$ & 83 & $153.39(109.32)$ & $75.33(36.89)$ & $3.5(0.74)$ & 98 & $17.43(4.27)$ & $4.92(2.04)$ \\
\hline $\mathrm{Py}$ & 93 & $188.32(132.14)$ & $145.32(81.79)$ & $2.58(1.03)$ & 88 & $15.86(5.7)$ & $7.11(4.99)$ \\
\hline $\mathrm{Cu}$ & 90 & $92.12(79.61)$ & $147.91(107.25)$ & $2.36(1.29)$ & 94 & $35.55(6.61)$ & $6.51(2.72)$ \\
\hline
\end{tabular}

The combination of the flammability variables recorded on live fuel and dead fuel (litter) using hierarchical cluster analysis highlighted three groups of species with different flammability (Figure 3): the most flammable species (Phyllostachys sp. , Eleagnus ebbingei , Ligustrum japonicum and Nerium oleander), the least flammable species (Pittosporum tobira) and the group of species having intermediate flammability (Cupressus sempervirens, Prunus laurocerasus and Pyracantha coccinea). According to the type of fuel (live or dead), some species showed the same type of flammability like Pittosporum (always poorly flammable), Cupressus and Pyracantha (always moderately flammable) or Eleagnus (always highly/extremely flammable) in contrast of other species (Phyllostachys sp., Prunus laurocerasus , Ligustrum japonicum and Nerium oleander) which were less flammable at the live leaf than at the litter level.

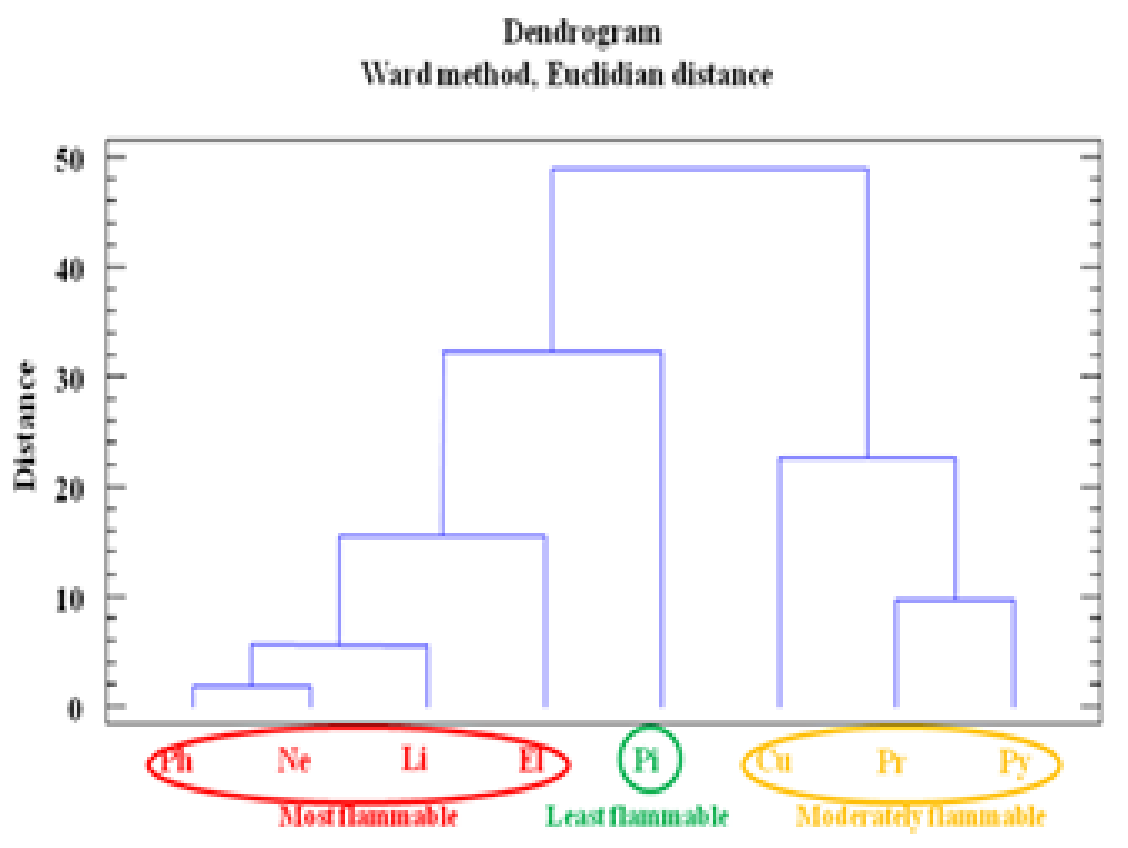

Figure 3 : Dendrogram of hierarchical cluster analysis based on the flammability variables recorded on live leaves (time-to-ignition, flaming duration, ignition frequency) and litters (time-to-ignition, flaming duration, ignition frequency, initial propagation) sampled in the different species studied (Ph: Phyllostachys sp., Cu: Cupressus sempervirens, Ne: Nerium oleander, Li: Ligustrum japonicum, El: Eleagnus ebbingei, Pi: Pittosporum tobira, Pr: Prunus laurocerasus and Py: Pyracantha coccinea) 


\subsection{Assessment of the fire risk}

The fire risk was assessed taking into account the flammability of the main ornamental species, the type of vegetation adjoining environment of the housing, the type of fence, the structure of the hedges and the implementation of the regulation on brush-clearing.

Among these descriptive parameters, some can mitigate the fire propagation toward the housing, thus mitigate the fire risk, such as crops and another garden as vegetation types adjoining the environment of the housing, discontinuous hedges or high wall surrounding the housing. Poorly flammable species (like Pittosporum) as well as the implementation of the regulation on brush-clearing around the housing also contribute to mitigate the fire risk. On the contrary, other parameters can enhance the fire risk, such as shrubland and forest adjoining the environment of the housing, the absence of fence or fence made of wire that cannot mitigate the radiant heat or the firebrands emitted by the flaming vegetation. Continuous hedges, particularly composed of very flammable species as well as the nonimplementation of the regulation on brush-clearing can also enhance fire propagation toward the housing.

The multivariate analysis showed that the fire risk increases from the dense and very dense clustered WUIs to the isolated and scattered WUIs on axis 1 with a gradient of fire risk from low fire risk (other garden, high wall, discontinuous hedges) to high fire risk (shrublands which means a vegetation burned at least one time, no fence or wire-made, continuous hedges). The presence of, at least, seven species characterized by intermediate or high flammability and no poorly flammable species in the isolated and scattered WUI types also indicates higher fire risk in these areas whereas the presence of at least one poorly flammable species and five species characterized by intermediate or high flammability in the dense and very dense clustered WUI types contribute to decrease the fire risk. The same trend as on axis 1 was also highlighted from the coastal area to the inland area on axis 2. Implementation of the regulation on brush-clearing was not a significant parameter in the analysis (Figure 4).

Factorial Plane $1 \times 2$

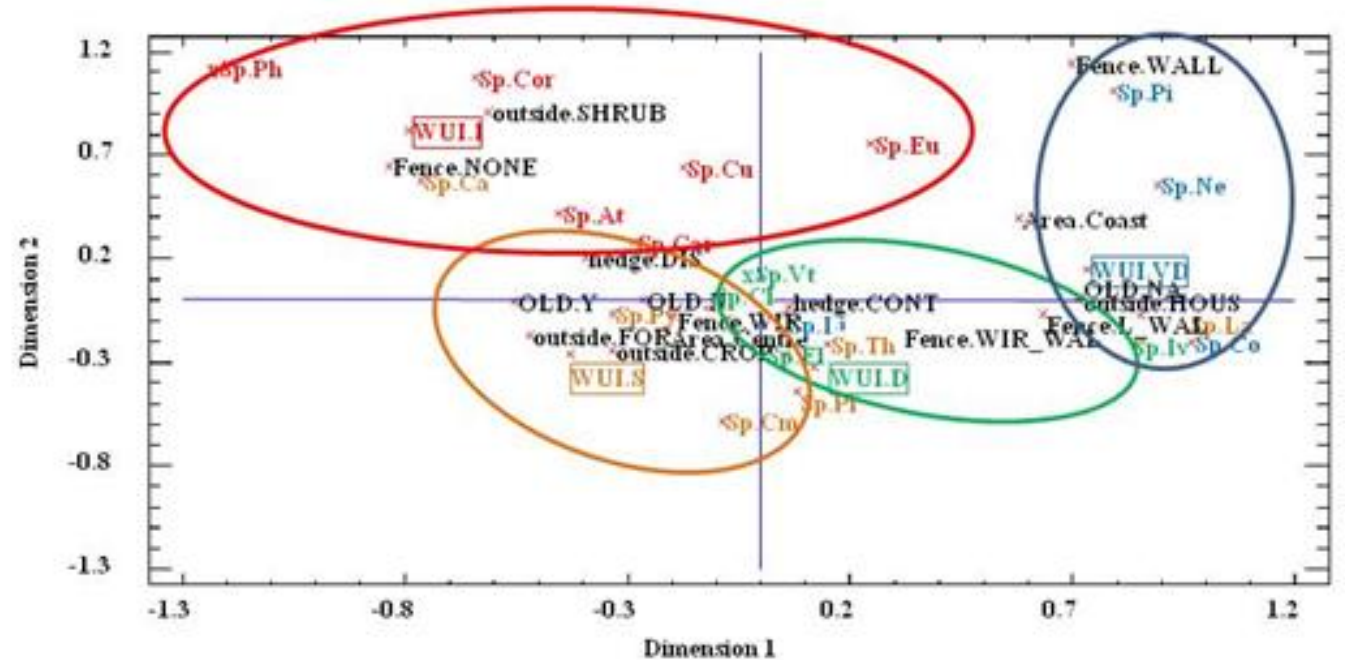

Figure 4. Factorial plane of the MCA showing the variation of the fire risk (red: high, orange: medium, green: low, blue: very low) between the different WUI types (I: isolated, S: scattered, D: dense clustered, VD: very dense clustered) and the location in the study area (coastal vs inland) according to the parameters recorded in the area surrounding the housing. (Sp: Ar: Arundo donax, La: Laurus nobilis, At: Atriplex maritimus, Cor: Coronilla sp., Ph: Phyllostachys sp., Cu: Cupressus sempervirens, Cm: Cupressus macrocarpa, Car: Cupressus arizonica, Li: Ligustrum japonicum, Pr: Prunus laurocerasus, Py: Pyracantha coccinea, Vt: Viburnum tinus, Cl: Cupressus leylandii, Th:

Thuja occidentalis, El: Eleagnus ebbingei, Eu: Euonymus japonicus, Ne: Nerium oleander, Pi: Pittosporum tobira, Co: Cotoneaster sp., He: Hedera helix;Outside: HOUS: house, FOR: forest, SHRUB: shrubland; Type offence:

WAL: high wall, L_WAL: low wall, WIR_WAL: wall and wire, WIR: wire; type of hedge: CONT: continuous, DIS: discontinuous; implementation of mandatory brush-clearing: OLD_Y:yes, OLD_N: No, OLD_NA: no data) 


\section{Conclusion}

The improvement of the knowledge on WUI environment at small scale will allow an increasing efficiency of the wildfire prevention targeting the areas most at risk. Assuming that the parameters recorded in the environment of the housing correspond to important aspects of fire risk, we showed that isolated and scattered WUI, especially in the inland area, are in fact at high risk of wildfire. This result agrees with the work of Lampin-Maillet et al. (2010) who also highlighted a higher fire risk in isolated and scattered WUI types than in the clustered types taking into account different fire metrics.

\section{Acknowledgements}

The authors wish to thank the Irstea's technical staff for their contribution in the field and in the burning experiements.

\section{References}

Anderson HE (1970) Forest fuel ignitability. Fire Technology 6, 312-319

Barbéro M, Loisel R, Quézel P, Richardson DM, Romane F (1998) Pines of the Mediterranean Basin. Ecology and Biogeography of Pinus. Cambridge University Press, Cambridge.

Caballero D (2004) Conclusions of the Third WARM Workshop on Forest Fires in the Wildland-urban Interface in Europe. Madrid, Spain, 26-27th of May.WARM Project Final Report. European Commission.

Camia A, Valera V, Marzano R, Etchifidis G (2003) Spatial Analysis in European Wildland-urban Interface Environment Using GIS. WARM project, http://www.fria.gr/chapters/warmCh21Camia. pdf.

Cohen JD (2000) Preventing Disaster- Home Ignitability in the Wildland-Urban Interface. Journal of Forestry 98(3), 15-21.

Cohen JD (2008). The wildland urban interface fire problem: a consequence of the fire exclusion paradigm. Forest History Today, 20-26.

Davis JB (1990) The wildland-urban interface: paradise or battleground? Journal of Forestry 88 (1), $26-31$.

Ganteaume A, Jappiot M, Lampin C (2013a) Assessing the flammability of surface fuels beneath ornamental vegetation in wildland-urban interfaces, in Provence (south-eastern France). International Journal of Wildland Fire 22(3), 333-342.

Ganteaume A, Jappiot M, Lampin C, Guijarro M, Hernando C (2013b) Flammability of some ornamental species in wildland-urban interfaces in Southeastern France: laboratory assessment at particle level. Environmental Management, 52, 467-480.

Haynes K, Handmer J, McAneney J, Tibbits A, Coates L (2010) Australian bush- fire fatalities 1990 2008: exploring trends in relation to the "Prepare, stay and defend or leave early" policy. Environmental Science Policy 13, 185-194.

Lampin C, Jappiot M, Long M, Mansuy N, Borgniet L (2006a) WUI and road networks/vegetation interfaces characterizing and mapping for forest fire risk assessment. Forest Ecology and Management 234 (Suppl. 1), S137-S140.

Lampin C, Jappiot M, Borgniet L, Long M (2006b) Cartographie des interfaces habitat-fore t: une approche spatiale pour estimer le risque d'incendie de forêt. Revue internationale de géomatique. European. Journal of GIS and Spatial analysis 16 (3-4), 321-340.

Lampin-Maillet, C., Jappiot, M., Long, M., Morge, D., Ferrier, J.P., 2009. Characterization and mapping of dwelling types for forest fire prevention. Computers, Environment and Urban Systems 33, 224-232. doi:10.1016/j.compenvurbsys.2008.07.003. 
Lampin-Maillet C, Jappiot M, Long M, Bouillon C, Morge D, Ferrier JP (2010) Mapping wildlandurban interfaces at large scales integrating housing density and vegetation aggregation for fire prevention in the South of France. Journal of Environmental Management 91, 732-74.

Mell WE, Manzello SL, Maranghides A, Butry D, Rehm RG (2010) The wildland-urban interface fire problem-current approaches and research needs. International Journal of Wildland Fire 19, 238251.

Quézel P (2000) Taxonomy and biogeography of Mediterranean pines (Pinus halepensis and $\boldsymbol{P}$. brutia). In: Néeman G and Trabaud L (eds.) Ecology, Biogeography and Management of Pinus halepensis and Pinus brutia Forest Ecosystems in the Mediterranean Basin, Backhuys, Leiden, NL, pp 1-12.

Quézel P, Barbero M (1992) Le pin d'Alep et les espèces voisines : répartition et caractères écologiques généraux, sa dynamique récente en France méditerranéenne. Forêt méditerranéenne XIII, 158-170.

Stephens SL (2005) Forest fire causes and extent on United State Forest Service lands. International Journal of Wildland Fire 14, 213-222.

Stewart, S.I., Radeloff, V.C., Hammer, R.B., Hawbaker, T.J., 2007. Defining the wildland-urban interface. Journal of Forestry, 201-207.

Vélez R (1997) Recent history of forest fires in Mediterranean area. In: Balabanis P, Eftichidis G, Fantechi R (Eds.), Forest Fire Risk and Management. Proceedings of the European School of Climatology and Natural Hazards, Greece, 27 May-4 June 1992. European Commission, Brussels, pp. 15-26. 